\title{
The Precarious Rationality of International Law: Critiquing the International Rule of Recognition
}

\author{
Alex Green ${ }^{1}(1)$ \\ ${ }^{1}$ Lecturer, York Law School, University of York, United Kingdom \\ Corresponding author: alex.green@york.ac.uk
}

(Received 03 December 2020; accepted 24 February 2021)

\begin{abstract}
Some scholars assume that the content and validity of international legal norms turns upon the existence of convergent attitudes and behaviors of state representatives and other 'international legal officials'. By converging upon the criteria for what counts as a 'formal source' of international law and what does not, such officials provide a 'rule of recognition' in relation to which the normative content of the international legal system is determined. In this Article I present two theoretical problems with this view, arguing that, depending on exactly what role this rule is intended to fulfil within international legal theory, it is either metaphysically insupportable or fundamentally at odds with the disagreements that persist in relation to the formal sources of international law. Both problems risk undermining the rationality of international legal argumentation and that any reliance upon the existence of an international rule of recognition should be eschewed as a result.
\end{abstract}

Keywords: Public International Law; Legal Philosophy; Legal Positivism; HLA Hart; Legal Reasoning

\section{A. Introduction}

In The Concept of Law, H.L.A. Hart denied that international law constitutes a fully-fledged legal system. His reasoning was that "there is no basic rule providing general criteria of validity for the rules of international law" or, to use his term of art, no rule of recognition. ${ }^{1}$ According to Hart, if the international legal system were to possess such criteria they would need to mirror the "complex, but normally concordant, practice of courts, officials, and private persons in identifying the law" that, on his account, determine content and validity of law within domestic systems. ${ }^{2}$ In other words, there would need to be a convergence of attitude and behavior amongst those international legal officials who apply the criteria that impart content and validity upon international legal norms. It is this convergence, and the criteria it grounds, that Hart believed lacking within international law.

\footnotetext{
Alex Green Lecturer, York Law School, University of York; Academic Associate, 23 Essex Street Chambers. This research was funded by the Hong Kong Research Grants Council and the Modern Law Review. Particular thanks are due to Jason Beckett, James Fry, Alexandra Hearne, Simon Palmer, Martins Paparinskis, Riz Mokal, and my anonymous reviewer at the German Law Journal. The usual disclaimer applies. Special thanks are also due to the efforts of the German Law Journal's student editors: their work was as meticulous as their patience was inexhaustible.

${ }^{1}$ H.L.A. Hart, The Concept of Law 236 (Joseph Raz \& Penelope A. Bulloch, eds. 3d ed. 1994).

${ }^{2} I d$. at 110 .
}

(C) The Author(s) 2022. Published by Cambridge University Press on behalf of the German Law Journal. This is an Open Access article, distributed under the terms of the Creative Commons Attribution licence (https://creativecommons.org/licenses/by/4.0/), which permits unrestricted re-use, distribution, and reproduction in any medium, provided the original work is properly cited. 
Contemporary scholars, including some committed to Hart's own theory of legal validity, have tended to reject this critique of the international legal system. ${ }^{3}$ Despite what Hart himself believed, several authors think it both possible and profitable to understand international law in broadly Hartian terms. ${ }^{4}$ Mehrdad Payandeh, for example, has argued for the wholesale applicability of Hart's philosophy to contemporary international law, ${ }^{5}$ whilst Jean d'Aspremont's formalist reading of legal validity explicitly asserts the existence of "an international rule of recognition." ${ }^{\text {" For }}$ such scholars, the relevant legal officials, amongst whom a convergence of attitude and behavior exist, are primarily state representatives, but may also include international courts and tribunals, United Nations treaty bodies, and certain respected publicists. ${ }^{7}$ Taken together, they are represented as producing a readily ascertainable set of criteria for the identification of international law, which correspond, in metaphysical terms, ${ }^{8}$ to the standards by which the international system establishes legal content and validity. ${ }^{9}$

In this Article, I examine the force of such arguments. However, unlike some of those who have done so before, I take no sides_-nor any particular interest-in whether or not Hart was right and whether international law can really be described as a legal system. Instead, my concern is more practical: Any attempt to ground international law upon a convergence of official attitudes and behavior not only misrepresents, but also actively undermines, the rationality of international law as a regulatory tool. In addressing these concerns, my target is not the internal coherence of Hart's positivism as such, nor its utility as a sociological account of law in general, but rather the consequences that relying upon Hartian assumptions might have as theoretical premises for concrete, practical, international legal argument. This being so, my problematization of the international rule of recognition is not only of philosophical interest. Instead, as I will argue, insofar as any doctrinal scholarship places undue reliance upon a convergence of official attitudes and behavior, it risks performatively replicating the inference that international law is grounded upon irrational foundations. This not only implicates scholars who explicitly accept Hart's philosophy but also those who assert or assume a similar convergence of official attitudes and behavior, such normative positivists like Samantha Besson or David Lefkowitz. ${ }^{10}$ In this sense, Hart's theory of legal validity provides a convenient lens through which to analyze broader trends within international legal scholarship.

With the above in mind, this Article will make two broad claims. First, in support of Hart, I contend that there must be some principle, rule, or set of reasons, capable of: (i) Imparting validity upon international legal norms; and (ii) explaining why such norms count as part of the international legal system whilst others do not. Second, I argue that whatever form these criteria take, there are significant reasons to doubt that they comprise a rule of recognition. Ultimately,

\footnotetext{
${ }^{3}$ See generally David Lefkowitz, What Makes a Social Order Primitive? In Defense of Hart's Take on International Law, 23(4) LEGAL THEORY 258 (2017).

${ }^{4}$ See Jeremy Waldron, International Law: “A Relatively Small and Unimportant” Part of Jurisprudence?, in READING HLA HART's ‘The Concept of LAw’ 209, 219-22 (Luís Duarte d'Almeida, James Edwards, \& Andrea Dolcetti eds., 2013).

${ }^{5}$ Mehrdad Payandeh, The Concept of International Law in the Jurisprudence of H.L.A. Hart, 21 EUR. J. INT'L L. 967, 989-93 (2010).

${ }^{6}$ Jean d'Aspremont, Formalism and the Sources of International Law: A Theory of the Ascertainment of LEGAL RULEs 195-220 (2011).

${ }^{7}$ Payandeh, supra note 5 , at $989-90$.

${ }^{8}$ Metaphysics as such is difficult to define. The metaphysical issues I contemplate in this Article mainly relate to the relationships of determination that exist between particular facts. For instance, fact A metaphysically determines fact B insofar as fact B is the case at least in part due to fact A being the case. See generally Samuele Chilovi \& George Pavlakos, LawDetermination as Grounding: A Common Grounding Framework for Jurisprudence, 25 LEGAL THEORY 53 (2019).

${ }^{9}$ Payandeh supra note 5, at 989-90.

${ }^{10}$ See, e.g., Samantha Besson, Theorizing the Sources of International Law, in THE PHILOSOPHy OF INTERNATIONAL LAW 163, 180-85 (Samantha Besson \& John Tasioulas eds., 2010). See also David Lefkowitz, The Sources of International Law: Some Philosophical Reflections, in The Philosophy of International LaW 187, 199-201 (Samantha Besson \& John Tasioulas eds., 2010).
} 
whilst Hart was correct to ask what determines the content and validity of international legal norms, he was looking for the wrong kind of foundation, at least from an internal, doctrinal perspective.

To illustrate why this matters, I begin by explaining the doctrine of sources, which provides the most commonly accepted theory of how to identify the existence and content of international legal norms. First, I show how we might plausibly interpret the doctrine of sources to hold that the content of international law is determined by a particular set of social facts. Facts of this kind take the form of true descriptive propositions about what has been done, said, or thought and, in the context of international law, include propositions about the semantic content of treaty documents, what state representatives have done and said, and so on. After expanding upon this picture, I show how it may well lead international lawyers to seek a rule of recognition-some convergence of official attitudes and behavior that picks out particular kinds of social facts as formal sources.

The critical argument of this Article has two stages. First, following Mark Greenberg, I contend that rules of recognition, by virtue of being social facts themselves, cannot provide a reason why some kinds of social fact count as formal sources of international law whilst others do not. This lack of explanatory power means that straightforward reliance upon the supposedly foundational role of an international rule of recognition will lack a rational basis. This critique speaks mainly to scholars like Payandeh and d'Aspremont, who invoke convergent attitudes and behavior as the ultimate basis of international law.

Second, I contend that even subsidiary reliance upon an international rule of recognition is deeply problematic. This argument speaks not only to those such as Payandeh and d'Aspremont, but also to normative positivists like Samantha Besson or David Lefkowitz, who accept that the content and validity of international legal norms rests ultimately upon moral foundations. ${ }^{11}$ My concern is that the instrumental reliance such scholars place upon convergent attitudes and behavior within the international legal system opens them up to a critique that has also been levelled at Hart himself: That it is by no means clear what level of consensus must hold in relation to the sources of law before sufficient convergence in official attitudes and behavior can be said to exist.

In the latter connection, I identify two equally problematic possibilities. On the one hand, perhaps such thoroughgoing consensus is required that the existence of a rule of recognition sits poorly with any significant disagreements about the sources of international law. On the other hand, maybe such minimal consensus is required that any seeming agreement on the criteria for international legal validity implies very little for how any resulting legal norms should be understood and applied. These alternatives risk rendering the idea of a rule of recognition either: (i) Inapplicable to international law by virtue of the contested nature of its criteria for legal validity; or (ii) unable to guide the identification of international legal norms in any sort of meaningful way.

One final point by way of introduction. The various charges of foundational irrationality I raise in this Article could - and in some cases have-been made against all accounts of legal reasoning that rely upon official consensus, whether they concern the international legal system or its many municipal equivalents. Nonetheless, as I shall argue, there are several features of international law-including its lack of a centralized institutional structure and its relative dearth of coercive enforcement mechanisms - that make my criticisms of Hartian scholarship particularly apt in this context. International law's capacity to function as an effective check upon state power-however limited that capacity may in fact be-turns in large part upon the ability of international legal argument to articulate intelligible reasons for action. No fundamentally irrational or performative argumentative practice can hope to do this. Therefore, on the reasonable assumption that those engaged in the practice of international law should seek to ensure that it continues to operate as

\footnotetext{
${ }^{11}$ See Besson, supra note 10 , at 175-78; Lefkowitz, supra note 10 , at $188-91$.
} 
"the gentle civilizer of nations," 12 they have particular cause to treat with suspicion any intellectual tradition that may promote irrational argumentative practices. Unfortunately, as I shall argue, the work of contemporary Hartians actively undermines argumentative rationality in precisely this manner.

\section{B. Rules of Recognition and the Doctrine of Sources}

The standard approach to identifying international legal norms requires one to 'trace' the validity of putative laws back to a recognized 'source'. This doctrine of sources discloses particular metaphysical assumptions about how the content and validity of international legal norms comes to be 'fixed' or 'determined'. As Thirlway characterizes this position, "the existence and content of all international law is best understood in terms of the system by which the various principles and rules have established themselves, i.e. a system of sources." ${ }^{13}$ In this section, I explain the doctrine of sources, first as described in the writings of contemporary publicists, and then in explicitly Hartian terms. My aim is not only to show why one might be tempted to view the sources of international law through Hart's jurisprudential lens but also to demonstrate that several international lawyers do. This matters because, as noted above, to the extent that the work of these publicists influences the way in which international law is practiced, any irrationality implicit therein is liable to infect that practice. Indeed, given what we know about the relationship between international law as a common intellectual enterprise, this risk seems almost inevitable and therefore all the more important to resist. ${ }^{14}$

\section{The Doctrine of Sources in International Law}

The formal sources of international law, which impart both legal validity and prescriptive content upon its constitutive norms, are often explained through contrast with its material sources. Unfortunately, this terminology is sometimes used in inconsistent ways. On the one hand, formal sources are often described as the "legal element that gives the rule its quality as law"15 or the elements "from which [a] legal rule derives its legal validity." ${ }^{16}$ On the other hand, they have also been characterized as "methods for the creation of rules of general application which are legally binding on their addressees" 17 and "processes by which [the] content [of a rule] is ... identified and usually modified to become law." 18 Similarly, whilst material sources are most commonly characterized as "the social origin[s] and other 'causes' of the law,"19 they have also been called "evidence of the existence of rules." ${ }^{20}$

To avoid this ambiguity, we must simplify matters. Legal standards all have legislative histories - sets of social facts that help to explain how they arose. For instance, the legislative history of a treaty will include how, where, and when its text was written, as well as what motivations led the relevant state representatives to adopt that particular text. Complete histories of this sort are invariably complex and only some of the facts they contain will bear any direct metaphysical relation to the eventual content of the law. To continue using treaties as an example, prior to the Convention on Fishing and Conservation of the Living Resources of the High Seas, many state

\footnotetext{
${ }^{12}$ See generally Martti Koskenniemi, The Gentle Civilizer of Nations: The Rise and Fall of International Law 1870-1960 (2009).

${ }^{13}$ Hugh Thirlway, The Sources of International Law 44-52 (2014).

${ }^{14}$ See generally Oscar Schachter, The Invisible College of International Lawyers, 72(2) Nw.L.REv. 217 (1977).

${ }^{15}$ ThIRLWAY, supra note 13 , at 6 .

${ }^{16}$ Robert Jennings \& ARThur Watts, Oppenheim's International LaW 23 (9th ed., 2008).

${ }^{17}$ James Crawford, Brownlie's Principles of Public International LaW 21 (8th ed., 2012).

${ }^{18}$ Besson, supra note 10 , at 170 .

${ }^{19}$ D. P. O'Connell, International Law 7 (2d ed. 1970).

${ }^{20}$ CrAWFORD, supra note 17 , at 21 .
} 
representatives may have been concerned about over-fishing. ${ }^{21}$ However, until this led to the signing and ratification of the relevant text, international law remained unaffected. Social facts, such as ratified treaty texts, that fix the content of international law directly are its formal sources. Facts, such as concerns about over-fishing, that indirectly contribute to this process - typically by playing a causal role in the creation of directly relevant facts-are international law's material sources.

The disparate characterizations quoted above all fit this version of the formal/material distinction. By contributing directly to the determination of international law, formal sources impart legal validity upon putative standards. Knowing what kinds of fact possess this potency also helps to identify international legal standards correctly. Conversely, by contributing to the determination of law further up the causal chain, material sources tell us about the "moral and social processes by which the content of international law is developed." 22 In some circumstances, such background facts can also be used as evidence of international law's content where that is in dispute, the classic example being the use of travaux préparatoires in the interpretation of treaties.

Article 38(1) of the International Court of Justice (ICJ) Statute is often characterized as containing the canonical list of formal sources. It reads:

1. The Court, whose function is to decide in accordance with international law such disputes as are submitted to it, shall apply:

(a) international conventions, whether general or particular, establishing rules expressly recognized by the contesting States;

(b) international custom, as evidence of a general practice, accepted as law;

(c) the general principles of law recognized by civilized nations;

(d) subject to the provisions of Article 59, judicial decisions and the teachings of the most highly qualified publicists of the various nations, as subsidiary means for the determination of rules of law. ${ }^{23}$

The judicial decisions and writings listed in subsection 1(d) - referred to there as subsidiary sources-are not generally considered to be sources of law themselves but rather means through which the content of legal standards can be clarified. ${ }^{24}$ Outside the sources listed in Article 38, the unilateral commitments of governments are considered by some scholars to count, either as an independent source of international obligations, or as inchoate treaties, ${ }^{25}$ whilst the writings of bodies such as the International Law Commission (ILC) and the International Committee of the Red Cross (ICRC) are held by some to be additional subsidiary sources. ${ }^{26}$ To streamline the analysis that follows, I will assume from this point on that only the social facts implicit in subsections 1(a) to 1(c) of Article 38 count as formal sources of international law. These include: The text of treaty documents, along with any relevant reservations; the behavior and statements of state representatives that suggest the existence of customary norms; and any textual or behavioral evidence of generally recognized legal principles that are neither customary nor treaty-based.

\footnotetext{
${ }^{21}$ Convention on Fishing and Conservation of the Living Resources of the High Seas, Apr. 29, 1958, 559 U.N.T.S. 285.

${ }^{22}$ Besson, supra note 10 , at 170 .

${ }^{23}$ Statute of the International Court of Justice art. 38 para. 1.

${ }^{24}$ Thirlway, supra note 13 , at 6 .

${ }^{25}$ Unilateral Acts of States: Rep. of the Working Grp. on Unilateral Acts of States, U.N. Doc. A/CN.4/L./703 (2006); Report of the International Law Commission, at 212-32, U.N. Doc. A/61/10 (2006); Nuclear Tests (Austl. v. Fr.), Judgment, 1974 I.C.J. 253, paras. 43-46 (Dec. 20); Nuclear Tests (N.Z. v. Fr.), Judgment, 1974 I.C.J. 457, paras. 46-49 (Dec. 20); Armed Activities on the Territory of the Congo (New Application 2002) (Dem. Rep. Congo v. Rwanda), Judgment, 2006 I.C.J. 6, para. 50 (Feb. 3); Thomas Frank, World Made Law: The Decision of the ICJ in the Nuclear Tests Cases, 69 AM. J. INT'L L. 612, 616-17 (1975); Hugh Thirlway, Concepts, Principles, Rules and Analogies: International and Municipal Legal Reasoning, 294 RECUEIL DES COURS 334 (2002); Thirlway, supra note 13, at 44-52; VAUGHAN LOWE, INTERNATIONAL Law 90 (2007); Rosalyn Higgins, Problems and Processes: International LaW and How we Use It 35-36 (1994).

${ }^{26}$ Crawford, supra note 17 , at $43-44$; Thirlway, supra note 13 at $18-19$.
} 
The standard view of the doctrine of sources insists that only the formal sources of international law have a direct law-determining role: They are not only necessary for the existence and validity of international legal norms but also sufficient. ${ }^{27}$ This is the nub of the connection between the doctrine of sources and Hart's positivism, and what enables a Hartian account of the international legal system to be both constructed and critiqued. As demonstrated in the following section, legislative histories alone are insufficient to explain why some social facts count as formal sources whilst others do not. What Hart's philosophy enables is an account of the criteria that determine which facts amongst these histories impart prescriptive content and legal validity upon putative norms. In the following subsection I describe Hart's approach and show it to be active within a significant volume of international legal scholarship.

\section{The Hartian Interpretation}

According to Hart, not only the formal sources of law but also its source-determining criteria are social facts. For those who accept his approach, what counts as a source of law is fixed or determined by the behavior and attitudes of law-applying officials, which, in the international context, includes those of state representatives, international courts and tribunals, and so on. ${ }^{28}$ To unpack this notion, social facts only count as formal sources when they are treated as such by the relevant legal officials who, through their observable behavior, demonstrate a belief that those social facts have a direct bearing upon the validity of international law. ${ }^{29}$ This shared and performative practice, which exists as a matter of social convention, constitutes, for Hart, a legal system's rule of recognition. We can capture this idea by saying that the formal sources of international law determine the content and validity of that law because the convergent attitudes and behavior of state representatives, international judges, and so on, treat them as doing so. To take just one example, norms that can be inferred from the semantic content of treaty texts would, on this view, possess both their prescriptive content and legal validity because state representatives (and others) treat this as being so. ${ }^{30}$ To use d'Aspremont's language, the existence and validity of international legal norms is, in this sense, a "product of the collective consciousness" of those who practice international law's rule of recognition. ${ }^{31}$

D'Aspremont is not alone in viewing the doctrine of sources in predominantly Hartian terms. Noora Arajärvi, for example, asserts "the necessity of a coherent theory of sources in international law which ... explains developments in the social practice of international law" and explicitly cites the existence of a more-or-less determinate rule of recognition as an essential premise of that theory. ${ }^{32}$ In a similar vein, Lefkowitz maintains that at least customary international law rests upon a rule of recognition, ${ }^{33}$ whilst Besson argues that both the normativity and democratic legitimacy of all international law relies upon its possessing a single, unifying, rule of this kind. ${ }^{34}$

\footnotetext{
${ }^{27}$ Thirlway, supra note 13 , at 8-9.

${ }^{28}$ Compare Fábio Perin Shecaira, Source of Law are not Legal Norms, 26 RATIO JURIS 15 (2015), with Grant Lamond, Legal Sources, the Rule of Recognition, and Customary Law, 59 AM. J. INT'L L. 25 (2014).

${ }^{29}$ Hart, supra note 1, at 102, 108-09, 116-17; Jean D'Aspremont, Herbert Hart in Today's International Legal Scholarship, in International Legal Positivism in a Post-Modern World, 114, 122 (Jörg Kammerhofer \& Jean D’Aspremont eds., 2014).

${ }^{30}$ See Brian Tamanaha, A General Jurisprudence of Law and Society 142 (2001) (suggesting that legal officials are "whomever, as a matter of social practice, members of the group—including legal officials themselves-identify as 'legal' officials").

${ }^{31}$ JeAn D'Aspremont, International LAW AS A BeLief System 41 (2017).

${ }^{32}$ Noora Arajärvi, Is There a Need for a New Sources Theory in International Law? A Proposal for an Inclusive Positivist Model, 106 Proceedings of the ASIL Annual Meeting 370, 370-73 (2012). See also Frederick Schauer, Sources in LegalFormalist Theories: A Formalist Account of the Role of Sources in International Law, in THE OXFORD HANDBOOK OF THE SOURCES OF INTERNATiONAL LAw 384 (Samantha Besson \& Jean d'Aspremont eds., 2017).

${ }^{33}$ Lefkowitz, supra note 10 , at 200.

${ }^{34}$ Besson, supra note 10 , at $180-85$.
} 
Somewhat more obliquely, Thirlway claims that "for the purposes of the application of international law, there is in effect a principle, or a fundamental rule, that only those recognized sources may be referred to, or relied on, as creative of rules of international law," adding that "at some point all regulatory systems have to build their structure on some agreed and convenient starting point." ${ }^{35}$ Whilst not an explicit invocation of Hart, this use of "recognized" and "agreed" certainly intimates the importance of convergent attitudes and behavior. This is confirmed by Thirlway's characterization of Article 38 of the ICJ Statute as "derived from the relations built up among States ... [and containing] what was, in the view of those who drafted it, already there." ${ }^{\prime 3}$

Characterizations of this kind are, I suggest, largely typical within contemporary scholarship on the doctrine of sources. Indeed, as noted by Benedict Kingsbury, "[t]he dominant line among international lawyers now is to ... propos[e] a rule of recognition ... so as to render international law a unified system." ${ }^{37}$ Nonetheless, notwithstanding the widespread nature of this trend, it faces two significant philosophical difficulties. In what follows, I address each in turn, paying special attention to the deleterious implications they have for the rationality of international legal argument.

\section{Rules of Recognition and the Determination of International Law}

The first such difficulty applies to any theory that takes the convergent attitudes and behavior of legal officials to form the ultimate and exclusive metaphysical foundation of international law. This difficulty is entailed by a basic philosophical conundrum and is distinct from the separate issues raised below. ${ }^{38}$ In this section, I detail the nature of this conundrum, why Hart's philosophy fails to address it, and why international lawyers should be concerned about its existence.

As noted above, the social facts that comprise the formal sources of international law are not laws themselves. ${ }^{39}$ However, they at least partly determine the content and validity of international legal norms, so that if those social facts were in some way to change, these norms would change as well. ${ }^{40}$ We can capture this by saying that these facts constitute determinants of international law. In addition to the social facts referenced by the doctrine of sources, there are facts about the content of international law itself: The rules, principles, and so on, which govern international relations. Legal argument both assumes and confirms that at least some facts about these normative elements exist and that they are capable of being identified. ${ }^{41}$ Some social facts, such as treaty texts and tribunal judgments, may contain statements about the content of international law but they are not identical with the norms they describe. The philosophical problem lawyers face is the need to explain why particular social facts, like treaty texts, determine the content and validity of law. Why, in other words, certain social facts count as formal sources whilst others do not. Unless the determinative role of these formal sources is rationally intelligible, the practice of international law is at risk of appearing irrational and performative-a thinly veiled mask for global realpolitik.

I argue that any theory of international law that hopes to be of use to those of us engaged in the practical business of international legal argumentation must contain some account of why the content and validity of that law is established by the relevant social facts. Such an account must supply reasons capable of providing a suitably justified answer to that question and thereby, to use Mark Greenberg's phrase, explain why the formal sources of international law "rationally

\footnotetext{
${ }^{35}$ Thirlway, supra note 13 , at 8 .

${ }^{36} I d$. at 10 .

${ }^{37}$ Benedict Kingsbury, The Concept of 'Law' in Global Administrative Law, 20 EuR. J. INT'L L. 23, 28 (2009).

${ }^{38}$ The problem(s) of consensus discussed in Section 4 affect all theories that rely upon the existence of an international rule of recognition-including those theories that do not assert the ultimate or foundational status of such a rule.

${ }^{39}$ See Ronald DWORKIn, LAW's EMPIRE 7-11 (1986).

${ }^{40}$ See Mark Greenberg, How Facts Make Law, 10 Legal Theory 157, 164 (2004).

${ }^{41} I d$. at 162.
} 
determine" the content of its norms. ${ }^{42}$ The extent of this philosophical challenge is acknowledged by Greenberg:

A deep feature of our legal practice is that claims about the way in which factors contribute to the content of the law must be backed by reasons. Now, if we are to avoid a regress (or an infinite circle) of reasons, there must be a fundamental answer that does not itself rest on further reasons. Intuitively, however, the reason-based nature of our practice means that not just anything could qualify as the fundamental answer. ${ }^{43}$

For Hart, the rule of recognition, which is to say the convergent attitudes and behavior of the relevant legal officials, is what supplies the fundamental answer in question. In what follows, I illustrate why this contention cannot hold in relation to international law and what is risked, in terms of its observable rationality, by claiming or behaving otherwise. I begin by setting out exactly what is at stake should international lawyers fail to appreciate this metaphysical problem. Next, I demonstrate the practical reality of the problem through an extended thought experiment. Finally, I show why Hart's philosophy is unequal to the task.

\section{Why Rational Intelligibility Matters}

Social facts cannot brutely determine international law in the way that a particular manner of phrasing happens, perhaps inexplicably, to make something funny. ${ }^{44}$ We cannot experience or observe international legal norms when, say, reading a treaty text. To reach conclusions about such things we must engage in legal reasoning. But this necessarily assumes there to be reasons why particular social facts have the effect they do and that these reasons, when properly articulated and understood, will explain why particular legal standards arise from particular collections of such facts. ${ }^{45}$ Most international lawyers, I think, at least implicitly accept this. ${ }^{46}$ But this means that we should also accept that practically useful legal theories must elucidate the nature of those reasons in a sufficiently convincing manner. Any purported explanation of international legal validity that is incapable of doing so provides us with no rational basis upon which to make legal judgments.

By following such a theory, we might, by accident as it were, reach correct answers about the content and validity of some international law, some of the time. However, we would be unable to demonstrate why those conclusions were correct, nor could we test them for error. Our inability to accomplish either task would fundamentally undermine the observable rationality of our arguments, which would deal a devastating blow to the credibility of international law as a tool for global governance. ${ }^{47}$ Given the vast disparities in power that exist between contemporary states, ${ }^{48}$ and the absence of a world government capable of global law enforcement, the immanent rationality of international law represents its best hope for securing state compliance and settling interstate disputes. ${ }^{49}$ Any reliance upon a metaphysics of international law that brings such rationality

\footnotetext{
${ }^{42}$ Greenberg, supra note 40 , at 160.

${ }^{43}$ Mark Greenberg, The Moral Impact Theory, the Dependence View and Natural Law, in The CAmbridge COMPANION TO Natural LaW Jurisprudence 275, 305 (George Duke \& Robert George eds., 2017).

${ }^{44}$ Greenberg, supra note 40 , at 171.

${ }^{45} \mathrm{Id}$. at 164 .

${ }^{46}$ It is difficult to understand why we insist upon supplying argumentative justifications for our legal conclusions if we did not assume as much.

${ }^{47}$ Martti Koskenniemi, The Politics of International Law, 1 EUR. J. INT'L L. 4, 7-9 (1990).

${ }^{48}$ See generally Gerry Simpson, Great Powers and Outlaw States: Unequal Sovereigns in the International LEGAL ORDER (2009).

${ }^{49}$ See Prosper Weil, Towards Relative Normativity in International Law?, 77 AM. J. INT'L L. 413, 421 (1983); Jason Beckett, Behind Relative Normativity: Rules and Process as Prerequisites of Law, 12 EUR. J. INT'L L. 627 (2001); MORTIMER SELLERS, Republican Principles in International LaW: The Fundamental Requirements of a Just World Order 171 (2006). But see Jack Goldsmith \& ERIC Posner, The Limits of International LaW (2007).
} 
into doubt risks unseating its regulatory utility. To forestall this eventuality, practically useful theories must demonstrate the fundamental rationality of international legal argument by articulating, in a sufficiently convincing manner, the metaphysical connection between the social facts referenced by the doctrine of sources on the one hand, and the content of the law on the other hand.

The importance of this theoretical instrumentality is neatly captured by Dworkin's distinction between 'sociological' and 'doctrinal' theories of law. ${ }^{50}$ In sociological terms, "[i]t might be helpful or even essential for various purposes to stipulate a precise definition of what kinds of social structure counts as a legal system: to facilitate predicative social science, or to organize a research project, or to illuminate history in some way." ${ }^{51}$ However, all such definitions are more or less mutable. As long as our particular sociological usage is clearly explained and of analytical utility, no one can have any substantive cause to object on the basis that they employ a different and incompatible descriptive framework. It is worth noting, for example, that I make absolutely no objection, either in this Article or elsewhere, to the adoption of a Hartian framework for purely sociological purposes. I might doubt the existence of an international rule of recognition in descriptive terms - as discussed in Section D-but my objection to relying upon convergent official attitudes in international legal argument has little to do with whether or not such doubts call into question the legal nature of international law on the Hartian view.

Matters are quite different when turning to doctrinal questions. To once again quote Dworkin, theories of this kind concern "what the law requires or prohibits or permits or creates, and we share a great many assumptions about the kinds of argument that are relevant in defending such claims and also about the consequences that follow when such claims are true." 52 Unlike competing sociological theories, which can coexist on the understanding that we can categorize different kinds of phenomena as legal for different purposes, competing doctrinal theories of the same legal system are necessarily antagonistic. If you and I disagree about what international law requires on a given point, or what kind of argument would be sufficient to settle our disagreement, there is no meaningful sense in which we can both be correct: logically, either one or both of us must be mistaken. ${ }^{53}$

As such, it is of far more consequence which theories of law we presuppose when we engage in practical—-that is, doctrinal-international legal argumentation. Different legal theories will lead to different argumentative approaches and support claims that are based on different assumptions. Crucially, at least for present purposes, any theoretical approach that cannot render it rationally intelligible how particular legal norms are derived from the relevant social facts will fail in two respects. First, it will fail to mirror the fact, observed by Greenberg, that all practices of legal argumentation are fundamentally ones in which justificatory reasons are offered. Second, and most importantly for present purposes, such a theory will risk the replication of irrational and performative argumentative practices, which will undermine the regulatory utility of international law for the reasons described above. Representing legal argumentation as irrational and performative might be justifiable in sociological terms: Sociologists of law are external observers, with all the intellectual freedom that entails. However, once theoretical arguments move from the sociological to the doctrinal - that is, from the external task of disinterested observation to the internal role of underwriting argumentative participation-then that freedom becomes curtailed by responsibility. Rational intelligibility matters not just because it fits what one might call the phenomenology of international legal reasoning but also because our failure to seek it out can itself become a performative act. By adopting an ultimately irrational approach to legal argumentation, we risk collectively enacting the performativity of international law.

\footnotetext{
${ }^{50}$ Ronald DWorkin, JUstice In Robes 2-3 (2006).

${ }^{51} I d$. at 3 .

${ }^{52}$ DwORKIN, supra note 50 , at 2.

${ }^{53}$ This holds, of course, even if the answers to such questions are indeterminate.
} 


\section{Rational Determination in International Law}

For the content and validity of an international legal norm to be rationally determined, there must at least one social fact and a reason for deriving at least one such norm from that descriptive proposition. But there must also be some additional fact-something beyond the relevant sources and legal standards in question - that is capable of grounding the kind of reason that would render the determination of law rationally intelligible. ${ }^{54}$ Consider Greenberg's example of conceptual truth providing such a reason in a non-legal context: "That John is walking entails that John is moving. This entailment is rationally intelligible in virtue of the conceptual truth that one who is walking is moving." 55 In the above example, the fact of John walking corresponds, in the legal case, to the kinds of social fact with which we are concerned. Similarly, the fact that John is moving corresponds to the relevant facts about the content of the law. ${ }^{56}$ It is intelligible to us that John is moving because an additional set of facts-conceptual truths about walking and moving - allow us to deduce this. It is rational for us to make this deduction because those conceptual truths are sufficient to ground a reason to do so.

So too must it be when deriving international law from its formal sources. We need some additional fact-or a set of facts - that allow us to establish a rationally intelligible connection of metaphysical determination between international law's formal sources and its norms. ${ }^{57}$ For Hart, it is the rule of recognition that accomplishes this explanatory and metaphysical work, with the convergent attitudes and behaviors of the relevant legal officials constituting the additional facts required to bridge the gap. In what follows, I show why this suggestion cannot provide a rationally intelligible solution. First, however, I demonstrate the practical importance of rational determination within international legal argument.

It might seem counter-intuitive that the formal sources of international law cannot determine their own legal salience. After all, the legal relevance of a treaty text, for example, seems too obvious to merit further explanation. But even where social facts come in written form and have terms with a clear meaning in ordinary language, their non-legal meaning does not always correspond to their legal relevance. ${ }^{58}$ In the case of treaty interpretation, it has been said that where "the relevant words in their natural order and meaning make sense in their context, that is an end to the matter." ${ }^{\prime 9}$ However, this is not always so. When interpreting the United Nations Charter, the ICJ often departs from the ordinary meaning of particular words to ensure that UN organs have legal scope to properly fulfill their functions. ${ }^{60}$ More generally, where other parts of a treaty

\footnotetext{
${ }^{54}$ Greenberg, supra note 40 , at 166.

${ }^{55} \mathrm{Id}$. at $165-66$.

${ }^{56}$ This analogy is not exact. The fact that John is walking and the fact that John is moving are facts of the same kind: descriptive propositions about an empirically ascertainable entity. Conversely, the social facts that comprise the formal sources of international law are different in kind from the normative facts that comprise its prescriptive content. Nonetheless, the relation Greenberg's example brings out — that is, one of "rational determination"-is the same in both cases, so the analogy remains instructive.

${ }^{57}$ For some non-Hartian positivists, particularly those drawing upon the work of Hans Kelsen, conceptual truths analogous to those just contemplated supply facts of this kind: HANS KELSEN, PRINCIPLES OF INTERNATIONAL LAW 408-18 (The Lawbook Exchange ed., 2003) (1952); Jörg Kammerhofer, Hans Kelsen in Today's International Legal Scholarship, in INTERNATIONAL Legal Positivism in a Post-Modern World 81, 94-96 (Jörg Kammerhofer \& Jean D’Aspremont eds., 2014); Joseph Raz, Two Views of the Nature of the Theory of Law: A Partial Comparison, 4 Legal Theory 249 (1998); JOSEPH RAZ, The Authority of Law: Essays on LaW and Morality 51-52, 87-88, 108, 116 (1974); Joseph Raz, Practical Reason AND NORMS 126, 133-34, 149-52 (1999).

${ }^{58}$ Greenberg, supra note 40 , at $174-76$.

${ }^{59}$ Competence of the General Assembly for the Admission of a State to the United Nations, Advisory Opinion, 1950 I.C.J. Rep. 4, 8 (3 Mar.)

${ }^{60}$ International Status of South West Africa, Advisory Opinion, 1950 I.C.J. 128 (July 11); South West Africa (Liber. v. S. Afr.), Preliminary Objections, 1962 I.C.J. 319, (Dec. 21); Legal Consequences for States of the Continued Presence of South Africa in Namibia (South West Africa) notwithstanding Security Council Resolution 276 (1970), Advisory Opinion, 1971 I.C.J. 16, 47-50 (June 21); Certain expenses of the United Nations (Article 17, paragraph 2, of the Charter), Advisory Opinion, 1962 I.C.J. 151, 198-215 (July 2) (separate opinion by Fitzmaurice, J.).
} 
text, something unusual in the context of negotiations, or more abstract questions about the agreement's object and purpose, indicate that the ordinary meaning of the relevant words are insufficient to account for their legal relevance, their ordinary meaning is often nuanced or departed from outright. ${ }^{61}$ Beyond the law of treaties, a great deal of state practice relevant to the determination of customary law - by virtue of being a series of physical actions taken by state representatives - has no linguistic content to be read in line with ordinary usage. Indeed, social facts such as the moving about of ships or troops cannot really be said to have just one non-legal meaning: Something beyond such items of practice must fix this.

The point here is not that identifying the legal relevance of a treaty provision or item of state practice will always be difficult or that any attempt to do so will lack a rational basis, only that we need something beyond the fact of those provisions or actions for their legal meaning to be fixed and become identifiable. This is the role that rules of recognition are designed to fill. In a manner analogous to the conceptual truths that permit us to deduce John's movement from the fact that he is walking, the convergent attitudes and behavior of international legal officials are supposed to pick out particular social facts as formal sources of law.

Nonetheless, one might still be tempted to think that this kind of metaphysical bridge was unnecessary. For instance, perhaps we could instead appeal to another recognized source of international law, which seems to imply the legal relevance of the source with which we are more immediately concerned. For example, why can the legal salience of the Vienna Convention on the Law of Treaties not be determined by a range of statements from international tribunals and state representatives to the effect that it contains true statements of international law? Such pragmatism certainly seems to accord with the manner in which international law is practiced. Unfortunately, this approach would beg the question, and in any event lead to infinite regress, because the legal relevance of the latter sources must also be established. ${ }^{62}$ There can be no rational basis for assuming that some social facts are foundational whilst others are not. ${ }^{63}$

It might seem natural to avoid unmotivated foundationalism by viewing the formal sources of international law in a holistic manner. Suppose that we attempt to show why one source determines the content of international law by pointing to a second that indicates this, in much the same way as with the Vienna Convention above. However, rather than taking this second source to be foundational, we point to a third source that points to its salience, and so on. We might eventually close the circle and construct a network of social facts, each determining the legal salience of another, without any one fact being considered foundational. In this way-or at least so it seems - each source of international law would have its relevance determined by something beyond its own existence, without the need to go beyond the realm of social fact in order to find something to fill this role.

The difficulty with this supposed solution is that, for any given set of social facts, there will be a potentially infinite number of putative legal norms that they might entail. ${ }^{64}$ Many of these potential standards may seem absurd and strike as clear non-starters. Some will appear more appropriate as candidate international laws. However, we must have some reason to believe that a

\footnotetext{
${ }^{61}$ Vienna Convention on the Law of Treaties art. 31 para. 2, May 23, 1969, 1155 U.N.T.S. 331; Competence of the Int'l Labour Org. to Regulate the Conditions of the Labour of Persons Employed in Agriculture, Advisory Opinion, 1922 P.C.I.J. (ser. B) Nos. 2-3 (Aug. 12); Free Zones of Upper Savoy and the District of Gex (Fr. v. Switz.), 1932 P.C.I.J. (ser. A/B) No. 46, 140 (June 7); Liber. v. S. Afr. 1962 I.C.J. at 335 (Dec. 21); Young Loans Arbitration (Belg., Fr., Switz., U.K., \& U.S. v. Fed. Rep. Ger.), 59 I.L.R. 494, 534-40, 556-58 (1980); Arbitral Award of 31 July 1989 (Guinea-Bissau v. Sen.), Judgment, 1991 I.C.J. 53 (Nov. 12); Rights of Nationals of the United States of America in Morocco (Fr. v U.S.), Judgment, 1952 I.C.J. 176, 183-84, 197-98 (Aug. 27); Sovereignty over Pulau Ligitan and Pulau Sipadan (Indon./Malay.), Judgment, 2002 I.C.J. 625, 645-46, 651-53 (Dec. 17).

${ }^{62}$ For an analogous argument, see George Letsas, Strasbourg's Interpretive Ethic: Lessons for the International Lawyer, 21 EUR. J. INT'L L. 509, 534 (2010).

${ }^{63}$ Greenberg, supra note 40 , at $179-80$.

${ }^{64} I d$. at 181 .
} 
particular set of legal standards is the one that really follows from the sources in question. The problem is that these reasons cannot be provided by the social facts themselves: Even our rejection of obviously absurd standards must rely on something beyond these facts. Once again, this argument is not intended to problematize legal reasoning at the international level. Rather, it is designed to show that when we identify a legal position on the basis of some collection of social facts, we necessarily assume that the laws we identify are partly fixed by something beyond the facts we are examining.

To illustrate this point, consider the Jurisdictional Immunities case. ${ }^{65}$ Germany's complaint in that matter was, amongst other things, that Italy had committed an international wrong by facilitating domestic civil claims against it for breaches of humanitarian law perpetuated on Italian soil. Such claims, Germany argued, violated its state immunity. ${ }^{66}$ Because there was no relevant treaty law, the ICJ examined state practice and opinio juris. They identified a general principle of customary international law that gave foreign states immunity from domestic civil litigation. ${ }^{67}$ Under most circumstances this would naturally cover the acts of German armed forces. However, it stood to be determined whether, in this case, Germany did not enjoy immunity because the acts subject to civil claim in Italy were "delicts occasioning death, personal injury or damage to property committed on the territory of the forum State, and ... involved the most serious violations of rules of international law of a peremptory character for which no alternative means of redress was available." 68 The Court found that international practice to indicate that immunity continued to be enjoyed in cases of delicts occasioning death, personal injury or damage to property committed on the territory of the forum state. ${ }^{69}$ As to the relevance of Germany's acts being grievous international crimes breaching jus cogens principles for which no other means of redress was available, the Court held, on the basis of overwhelming practice, that immunity was unaffected. ${ }^{70}$ As a result, they ruled that Italy's provision for domestic litigation against Germany was a violation of international law.

Now, imagine that the Court had come to a different conclusion on a patently absurd line of reasoning. Say they held that Germany had no claim, not because the balance of state practice and opinio juris favored Italy, but because neither state practice nor opinio juris were relevant to the determination of customary international law. In this fictional version of the Jurisdictional Immunities ruling, our imagined ICJ holds that although customary law had always been at least partly determined by state practice and opinio juris, this ceased to be the case at some point just before the material time in the dispute. Now, according to our imagined Court, customary international law has to be identified by flipping a coin, and Italy just happened to win the toss. Clearly such a ruling would be wrong, but the interesting question is why.

Say that Germany objected to this extraordinary ruling because it had absolutely no basis in what was hitherto considered to be the relevant social facts. No prior item of state practice or opinio juris, nor any academic or judicial commentary, mentioned that these elements would become inapplicable in the way that our hypothetical Court seems to think that they did. The Court could respond, with perfect logical consistency, that this is immaterial because, at the point at which the content of customary law ceased to be determined by state practice and opinio juris, what the traditional sources had to say about the content and validity of customary international law became irrelevant. Furthermore, any aspects of international practice that seemed to contradict the Court's finding at, or after, the relevant time in the Jurisdictional Immunities dispute

\footnotetext{
${ }^{65}$ Jurisdictional Immunities of the State (Ger. v It.; Greece intervening), Judgement, 2012 I.C.J. 99 (Feb. 3)

${ }^{66} \mathrm{Id}$. at para. 12.

${ }^{67} I d$. at paras. $122-23,125$.

${ }^{68} \mathrm{Id}$. at para. 125 .

${ }^{69} \mathrm{Id}$. at paras. $126-35$.

${ }^{70} I d$. at paras. $136-45$.
} 
would, ex hypothesi, be mistaken and in any case irrelevant, given the new means by which customary obligations stood to be determined.

Next, Germany might object that the Court overstepped their authority under the ICJ Statute, which directs them to apply "international custom, as evidence of a general practice, accepted as law." 71 The reply might be that the parties appointed them to resolve the dispute according to customary law and that is what they have done: It just so happened that, contrary to the wording of the Statute, customary law now had to be determined by coin toss. In the first place, as an international instrument attached to a multilateral treaty, the text of the Statute itself constitutes one-or more-of the social facts that became irrelevant after the crucial point in time. What is more, given the reasonable assumption that at least some legal instruments contain propositions of law that are either inaccurate or mistaken, our fictionalized ICJ could also claim that the Statute contained such an error by failing to account for how the determinants of customary law would alter.

My point is not that such arguments are plausible. They are not. The issue is what makes them implausible. Arguments such as these are logically consistent with any and all of the state practice and opinio juris that came to pass before, during, and after the Jurisdictional Immunities litigation. The claim that state practice and opinio juris stopped determining customary law at time $\mathrm{T}^{1}$ is logically consistent with any example of their determining role before $\mathrm{T}^{1}$, as well as with any purported instance of such practice after $\mathrm{T}^{1}$, as long as we allow for the possibility that some putatively relevant social facts reflect legal mistakes. This would also be consistent with any number of equally silly claims, such as "state practice determines customary law in every instance other than this one" or "opinio juris is relevant unless this Court decides otherwise." Past practice would, in exactly the same way, be consistent with more sensible claims, such as "customary law is, and will continue to be, at least partly determined by state practice and opinio juris." This being so, social facts by themselves leave indeterminate the question of which standards they support. Distinguishing absurd accounts of international law from sensible ones must require something beyond logically consistency with its formal sources.

\section{The Inadequacy of Hart's Solution}

Since it allegedly provides "general criteria of validity for the rules of international law," one would expect an international rule of recognition to solve problems of the sort contemplated above. That certainly seems to be the doctrinal position taken - or at least the theoretical assumption madeby contemporary Hartians, such as d'Aspremont, Arajärvi, and Thirlway. However, the problem with relying upon such rules to supply the additional element necessary to fix what counts as a formal source of law is that the actions and attitudes of state representatives, international judges, and so on, are themselves just another set of social facts. ${ }^{72}$ For example, the practice of recognizing treaty documents as sources of law is no different, qua social fact, from the practices surrounding the promulgation of those documents. As we have seen, facts of this type cannot determine their own salience, or the salience of other aspects of international legal practice. There must be some additional fact — or facts — by virtue of which the attitudes and behaviors of legal officials have this determining effect. ${ }^{73}$ Moreover, such additional facts must provide reasons why the attitudes of, say, state representatives have this effect. Because they are composed entirely of such attitudes and behaviors, Hartian rules of recognition themselves cannot supply such reasons, and any account of

\footnotetext{
${ }^{71}$ Statute of the International Court of Justice art. 38 para. 1(b).

${ }^{72}$ See Mark Greenberg, Hartian Positivism and Normative Facts: How Facts Make Law II, in EXPLORING LAW's EMPIRE: THE JURISPRUDENCE OF RONALD DWORKIN 273 (Scott Hershovitz ed., 2006).

${ }^{73} I d$. at 276 ("for any rule R (that specifies that standards with certain features are law), officials' Hartian dispositions for R make it the case that a legal system's law practices contribute to the content of the law in accordance with $\mathrm{R}$ and only in accordance with R (and if officials do not have Hartian dispositions for any such rule, then there are no legal facts).").
} 
international law that posits the foundational nature of such a rule will, as a result, lack a rational basis.

In a last-ditch attempt to defend the logic of the Hartian approach, we might observe that finding a rational way to identify the content of international law is often made easier by the law itself. At least some norms actively pick out particular social facts as legally salient. ${ }^{74}$ For instance, the legal relevance of the Vienna Convention on the Law of Treaties is partly determined by the principle that treaties bind their parties. However, whilst pacta sunt servanda may explain why treaties bind, why is that principle itself binding? State practice and opinio juris might explain why certain things are legally required, but what confers this potency upon them ${ }^{75}$ At some stage we must look for a reason grounded in something beyond the formal sources of international law that, in combination with those social facts, makes it intelligible why a particular set of legal norms should be taken to arise from them. This, it seems to me, presents a foundational problem with Hartian assumptions about the metaphysics of international law: No convergence of attitude and behavior, qua social fact, can provide reasons of the requisite kind on its own.

At this juncture the Hartian approach can be usefully contrasted with an altogether different tradition within international legal scholarship. This alternative can be found in the work of Oppenheim—amongst others ${ }^{76}$ — who famously contended that:

The science of international law is just as little as any other science an end in itself; it is merely a means to certain ends outside itself. And these ends are the same, as those for which international law has grown up and is still growing - primarily, peace among the nations and the governance of their intercourse by what makes for order and is right and just $\ldots .{ }^{77}$

Within this passage Oppenheim, perhaps unwittingly, establishes a far more metaphysically promising doctrinal foundation for the content and validity of international legal norms then that offered by any contemporary Hartian. To understand this foundation fully, it must be remembered that Oppenheim himself was an avowed positivist. To quote him again:

[T] he science of international law has no right to lay down ... [any] rule ... as really existent, and universally or generally recognized unless it can be ascertained that the members of the family of nations have customarily or by a law-making treaty accepted the rule ... It is no use drawing up definitions and principles which do not agree with the facts as evidenced by the practice of the state. ${ }^{78}$

The seeming incongruity of Oppenheim's assertions that: (i) International legal validity ultimately rests upon the values of peace, order, justice, and so on, and; (ii) the validity of individual norms must be identified solely with reference particular social facts, is best understood as a form of normative positivism, quite distinct from the methodological sort advocated by d'Aspremont, Arajärvi, Thirlway, and, of course, Hart. ${ }^{79}$ For Oppenheim, it is not the convergent attitudes and behaviors of legal officials that determines the content and validity of international law but rather what Greenberg calls "normative facts" about particular moral concepts, such as justice. ${ }^{80}$ To quote Kingsbury:

\footnotetext{
${ }^{74}$ Greenberg, supra note 40, at 179 .

${ }^{75}$ See Patrick Capps, Methodological Positivism in Law and International Law, in LAw, Morality, AND LEGAL PositivisM 9, 16 (K.E. Himma ed. 2004).

${ }^{76}$ See, e.g., Hersch Lauterpacht, The Grotian Tradition in International Law, 23 BRIT. Y.B. INT'L L. 1, 19-51 (1946).

${ }^{77}$ Lassa Oppenheim, The Science of International Law: Its Task and Method, 2 AM. J. INT'L L. 313, 314 (1908).

${ }^{78}$ Id. at $334-35$.

${ }^{79}$ Capps, supra note 75 .

${ }^{80}$ Mark Greenberg, On Practices and the Law, 12 Legal Theory 113, 113-15 (2006).
} 
Oppenheim's commitment to a positivist approach ... was not simply an assertion that a positivist concept of law was the only coherent one, but also embodied a normative or ethical view that a positivist understanding of international law was best able to advance the realization in international society of a higher set of values $\ldots{ }^{81}$

Assume that Oppenheim was objectively correct about the values that international should serve-peace, for example - in that he would have been right even if nobody had ever agreed with him. ${ }^{82}$ Normative facts about what values like peace, order, and so on genuinely require are capable of doing what social facts about the dispositions of legal officials could never do: Supply a foundational answer to why some social facts, like treaty texts, count as formal sources of law whilst others do not. Appropriately codified international agreements serve a coordinative function that is manifestly conducive to international peace and stability, which provides a justificatory reason for them to generate binding legal norms. Assuming that international law really should serve peace in this way, arguments of this kind-that is, those employing normative facts-make it rationally intelligible why treaty texts impart content and validity upon international legal norms.

Consider, on this basis, a different kind of answer to our imagined ICJ in their hypothetical Jurisdiction Immunities ruling. Rather than rely upon established attitudes and behaviors within the international community, which our imagined Court can, without difficulty, deem logically consistent with their extraordinary finding that customary international law should now be determined by coin toss, Germany could instead assert that the Court had failed to appreciate the relevant normative facts. The ICJ's error, they might say, was not logical but conceptual and moral: Their proposed change to the determinants of custom does not serve peace and friendly relations. What state would rely upon a legal system that mandated dispute resolution by chance alone? How could such a system guide official behavior or solve international coordination problems? Unless Germany could be shown to have somehow misunderstood the importance of law and order or made a logistical mistake about what it takes for coordination problems to be solved, there would be no convincing way for our imagined ICJ to answer. The use of normative facts accomplishes what reliance upon yet more social facts, whether through a rule of recognition or otherwise, never could. For these reasons, the normative positivism of Oppenheim, marked by its internal commitment to the justifiability and practical utility of international law, provides a far more apt foundation for the rationality of international legal argumentation than that adopted by any contemporary Hartian. ${ }^{83}$

\section{Rules of Recognition and International Consensus}

The philosophical conundrum discussed in the previous section affects only those theories that take the convergent attitudes and behaviors of international legal officials to form the ultimate and exclusive ontological foundations of international law. In this section, I address another concern, which is common not only to these sorts of theory but also to any account of international law that relies upon the existence of an international rule of recognition- even those which do so only subsiduarily.

Such theories include the normative positivism of Besson and Lefkowitz, who explicitly allege the existence of international rules of recognition alongside their acknowledgement that the

\footnotetext{
${ }^{81}$ Benedict Kingsbury, Legal Positivism as Normative Politics: International Society, Balance of Power and Lassa Oppenheim's Positive International Law, 13 EUR. J. INT'L L. 401, 431 (2002).

${ }^{82}$ Matthew Kramer, Objectivity and the Rule of LaW 4 (2007).

${ }^{83} \mathrm{My}$ point here is not that Oppenheim's moral position is necessarily correct, and I certainly do not mean to suggest that it is correct because Oppenheim stipulated as such. Instead, I mean to emphasize that normative facts are logically distinct from social facts vis-à-vis their reason-giving potency.
} 
ultimate foundations of international law are moral, rather than simply a matter of social fact. ${ }^{84}$ For them, like for Oppenheim, the fundamental ontology of international law rests upon values such as peace and legitimacy. However, unlike Oppenheim, both Besson and Lefkowitz take the convergent attitudes and behaviors of international legal officials to fulfill the intermediary metaphysical role of fixing what counts as a formal source of international law, in much the same way as Hart himself does within the domestic context. ${ }^{85}$ I suspect that something like this view of international legal validity captures quite widespread assumptions amongst international lawyers.

Take Prosper Weil, whose classic liberal understanding of international law is paradigmatic of the normative positivist approach. ${ }^{86}$ Weil's characterization of international law as an "aggregate of the legal norms governing international relations" may imply that his international legal ontology is closer to Oppenheim's than to Besson's or Lefkowitz's. ${ }^{87}$ However, Weil also clearly takes international law to comprise a "normative system" that exists in a "self-contained, self-sufficient world." ${ }^{88}$ In one sense, these comments are metaphysically agnostic, as apt to rest upon a presupposed Kelsenian Grundnorm as upon a partly empirical assumption about converging attitudes and behavior. Nonetheless, and particularly in light of his focus upon the characterizations of several formal sources given by, for example, the International Law Commission and the ICJ, ${ }^{89}$ Weil's normative positivism is at least consistent with the notion that a rule of recognition is instrumental to the content and validity of international law. ${ }^{90}$ As argued below, even the possibility that such paradigmatic accounts of international legal validity employ or assume Hartian legal metaphysics should cause us significant concern.

\section{The Challenges of Evincing Sufficient International Consensus}

The problems that concern me in this section turn on the following fact: For state representatives - and others - to produce convergent attitudes and behavior capable of determining the formal sources of international law, there must be consensus amongst them, whether articulated or otherwise, about which social facts count as formal sources. In other words, there must be at least some coincidence of belief about the criteria for international legal validity. ${ }^{91}$ But, as I shall argue, it is highly debatable whether this coincidence of belief exists, given the presence of widespread disagreement about how to identify international legal norms. Consider the following quotation from The Concept of Law:

[W] hereas a subordinate rule of a system may be valid and in that sense 'exist' even if it is generally disregarded, the rule of recognition exists only as a complex, but normally concordant, practice of courts, officials, and private persons in identifying the law by reference to certain criteria. $^{92}$

\footnotetext{
${ }^{84}$ Besson, supra note 10, at 175-78; Lefkowitz, supra note 10 , at 188-94.

${ }^{85}$ Besson, supra note 10 , at $180-85$; Lefkowitz, supra note 10 , at 200.

${ }^{86}$ Beckett, supra note 49 , at 627.

${ }^{87}$ Weil, supra note 49 , at 413 (emphasis added).

${ }^{88}$ Weil, supra note 49 , at 421.

${ }^{89} \mathrm{Id}$. at $424-29,433-38$.

${ }^{90} I d$. at $440-42$. Whilst Weil against the advisability of community-wide recognition forming the basis of international legal norms, his reserve was targeted: (i) At what was, at the time, becoming generally accepted as necessary and sufficient for customary law formation, and not at the metaphysical Salience of that general acceptance; and (ii) at the moral (de)merits of what was becoming accepted, and not at its legal effect).

${ }^{91}$ Hart, supra note 1, at 110; d'Aspremont supra note 29, at 124; LIAM MURPHY, WHAT MAKES LAW: AN INTRODUCTION TO THE Philosophy of LAW 35 (2014).

${ }^{92} \mathrm{HART}$, supra note 1 , at 110 .
} 
What level of concordance is required? Neither Hart nor his proponents are clear on this point. Jules Coleman sometimes suggests that legal officials would not be following the same rule if they did not agree on its application in the vast majority of cases. ${ }^{93}$ At other times however, he implies that there can be widespread agreement about the existence of a particular rule of recognition, even where there is significant disagreement about which social facts it fixes as legally salient. ${ }^{94}$ Andrei Marmor echoes this more liberal view:

[C] ontroversy over the content of a rule of recognition does not prove that there is no such rule. Even where there are several ways of understanding a rule (or anything else for that matter), there must be something there that people can understand differently and argue about. $^{95}$

This duality in the Hartian literature is made all the more confusing by a tendency, at times, to present rules as identical to their prescriptive content, whilst at other times distinguishing the existence of rules from questions about what they require. To compound this confusion, the same writers sometimes identify the content of a rule with its application whilst at other times distinguishing the content of a rule from how it is applied. ${ }^{96}$ Perhaps most perplexing is d'Aspremont's claim that the requisite degree of consensus "essentially requires a shared feeling of applying the same criteria." 97

So which is it: Extensive consensus, minimal consensus, or just a feeling? Each has its attendant problem. In what follows, I consider each in turn. Ultimately, my objections are twofold. First, there is no clear methodological agreement amongst international lawyers or philosophers about the extent of the consensus required. This ambiguity invites us to talk past each other whenever our disagreements about the content and validity of international legal norms turns solely upon their correspondence with the relevant social facts. Second, even when taken in isolation, none of the three understandings of consensus just canvassed map precisely onto the argumentative reality of contemporary international law.

These two points of critique should concern us for the same reasons I provided above when outlining the importance of rational intelligibility. Quite independently of whether it is sociologically fruitful to adopt a Hartian understanding of international law, the incorporation of unsustainable assumptions into the fundamentally doctrinal task of international legal argumentation risks doubling down upon any extant irrationality and undermining the utility of international law as a means for regulating state power. As such, the arguments that follow are not concerned so much with whether the international legal system is truly legal—or systematic —in the Hartian sense, nor with whether Hart's legal philosophy is internally coherent. Instead, they are motivated by a concern that reliance upon a broadly Hartian approach will replicate problematic performativity within international legal argument and so undermine the normative potential of international law. ${ }^{98}$

\footnotetext{
${ }^{93}$ Jules Coleman, The Practice of Principle 116 (2001).

${ }^{94} I d$. at 99.

${ }^{95}$ Andrei Marmor, Positive Law and Objective Values 6 (2001).

${ }^{96}$ See Thomas Christiano \& Stephan Sciaraffa, Legal Positivism and the Nature of Legal Obligation, 22 L. \& PHILO. 487, 492 (2003) (citing Coleman as doing both). See also Hart, supra note 1, at 246; MARMOR, supra note 95, at 7; D'ASPREMONT, supra note 6, at 201; d'Aspremont, supra note 29, at 144.

${ }^{97}$ D'Aspremont, supra note 6, at 201.

${ }^{98}$ For the same reasons, I am not particularly concerned to show that these issues are unique to international law-they are not-but rather that, by virtue of its institutional features, international law is particularly vulnerable to them. These institutional features, as outlined above, include the lack of any centralized institutional structure, an absence of coercive enforcement mechanisms, the disparity in power amongst states, and so on.
} 


\section{Extensive Consensus}

Take Coleman's suggestion that meaningful coincidence of belief requires legal officials to reach compatible conclusions in the vast majority of cases when it comes to identifying the formal sources of law. If such extensive consensus is necessary for rules of recognition, then international law arguably does not have one. Admittedly, it is true that an overwhelming majority of international lawyers endorse the doctrine of sources largely as set out in the ICJ Statute. That text has also been reproduced in a number of documents setting up other international courts and tribunals. However, the nature of the problem becomes apparent when one notes the extremely abstract nature of Article 38(1).

For instance, assume that we can discover at least some international law by identifying "international custom, as evidence of a general practice, accepted as law." ${ }^{\prime 9}$ Furthermore, assume that this requires at least two things: (i) Public statements or other indications on the part of state representatives that a particular law exists; and (ii) behavior in general conformity with that proposed law on the part of such representatives. ${ }^{100}$ Many questions persist. Is an individual state's consent necessary for such laws to become binding upon it? ${ }^{101}$ Should custom-constituting practice be drawn exclusively from state representatives? ${ }^{102}$ What is the relevance of UN General Assembly resolutions, or the judgments of international courts and tribunals? ${ }^{103}$ Can regional practice give rise to obligations limited by geographical area? ${ }^{104}$ Disagreement on such issues suggests that it would be overly optimistic to speak of an extensive consensus on the concrete criteria of validity for norms of customary international law, even if nominal consensus exists at higher levels of abstraction. ${ }^{105}$

If a meaningful and concrete consensus did exist, we would expect all disagreements about the identification of international law to concern who said and did what and when. ${ }^{106}$ We could then input this empirical data to our widely shared criteria of legal validity. But international legal disagreements are more substantive - and more theoretical — than this. Consider the response of the United States to the ICRC's study on customary international humanitarian law. ${ }^{107}$ The US doubted whether the state practice listed by the ICRC was sufficient to support the law identified

\footnotetext{
${ }^{99}$ Statute of the International Court of Justice art. 38(1)(b).

${ }^{100}$ See Michael Wood (Special Rapporteur on the Formation and Evidence of Customary International Law), Second Rep. on Identification of Customary International Law, U.N. Doc. A/CN.4/672, $\$ \$ 24-26$ (May 22, 2014). However, there remains some disagreement even at this level of abstraction: See Int'l L. Ass'n, Statement of Principles Applicable to the Formation of General Customary International Law, Sixty-Ninth Conf. (July 29, 2000); Michael Wood (Special Rapporteur on the Formation and Evidence of Customary International Law), First Report on formation and evidence of customary international law, UN Doc. /CN.4/663, \$\$ 89-91 (May 17, 2013).

${ }^{101}$ Lowe, supra note 25, at 26; Higgins, supra note 25, at 13-16, 21-22; C.L. Lim \& O.A. Elias, The Paradox OF CONSENSUALISM IN INTERNATIONAL LAW 28-33 (1998).

${ }^{102}$ See Alan Boyle, Soft Law in International Law-Making, in InTERnATIONAL LAW 141 (Malcolm Evans ed., 2006); Crawford, supra note 17 , at 37-41, 42-43.

${ }^{103}$ Waldron, supra note 4, at 216. See generally Andrew T. Guzman \& Timothy L. Meyer, International Common Law: The Soft Law of International Tribunals, 9 CHI. J. INT'L L. 515 (2009); Robert Briner, Role of International Tribunals in the Context of the Rule of Law, 23 INT'L Bus. LAW. 354 (1995); Gerald Fitzmaurice, The Future of Public International Law and of the International Legal System in the Circumstances of Today, in INSTITUT DE DroIT INTERNATIONAL, LIVRE DU CENTENAIRE 1873-1973: EVolution ET PERSPectives du Droit InTERNATIONAL 270-74 (1973); Jorge CASTANEDA, LEGAL EFFECTS of United Nations Resolutions (1970); Christopher Joyner, UN General Assembly Resolutions: Rethinking the Contemporary Dynamics of Norm-Creation, 11 CAL. W. INT'L L.J. 445 (1981).

${ }^{104}$ Crawford, supra note 17, at 29-30; Lim \& Elias, supra note 101, at 118-19; ANTHONy D'Amato, THE CONCEPT OF

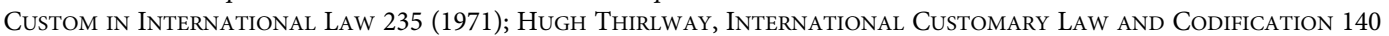
(1972).

${ }^{105}$ This is further evidenced by the highly abstract language and many equivocations found throughout the Statement of Principles Applicable to the Formation of General Customary International Law. See U.N. GAOR, 64th Sess. 3148 mtg. at 5-6, U.N. Doc. A/CN.4/SR.3148 (24 July 2012).

${ }^{106}$ DWORKIN, supra note 50, at $4-5,31,33,37$.

${ }^{107} \mathrm{See} \mathrm{JeAn-Marie} \mathrm{HencKaerts} \mathrm{\&} \mathrm{Louise} \mathrm{Doswald-Beck,} \mathrm{Customary} \mathrm{International} \mathrm{Humanitarian} \mathrm{Law} \mathrm{(2005).}$
} 
in their report. ${ }^{108}$ They also argued that too much emphasis was placed on written materials such as military manuals and General Assembly resolutions, whilst negative practice was given inadequate weight and that the ICRC failed to pay due attention to the practice of specially affected States. ${ }^{109}$ None of these criticisms alleged that the ICRC inaccurately represented the available social facts. Instead, each critique addressed the probative value of the social facts the ICRC relied upon. They were, in other words, not empirical but doctrinal, concerning the content of the criteria for identifying customary international law. Therefore, rather than suggesting a shared an understanding of those criteria, they evince contradictory beliefs about them.

Even within the case law of the ICJ there has been divergence on what counts as evidence of customary law, ${ }^{110}$ as well as on matters such as when binding unilateral declarations have been made, ${ }^{111}$ and on whether or not establishing state intent is necessary when identifying binding treaties. ${ }^{112}$ Compounding these disagreements is the fragmentation of approaches towards identifying law in different areas of international practice, such as international humanitarian law and human rights law. ${ }^{113}$ If judges in such areas apply different criteria for the identification of law from those in other areas of international legal practice, the case for an international rule of recognition grounded on an extensive consensus seems weak.

\section{Minimal Consensus}

Even accepting the above, it is difficult to see how anything less than an extensive consensus could be sufficient for the existence of an international rule of recognition, notwithstanding that some international legal scholars apparently believe otherwise. For example, both Arajärvi and Payandeh adopt what might be called a minimalist position on the requisite level of consensus, with the former referring to its "minimal substance" and the latter accepting it to be "characterized by severe incertitude," at least as far as customary international law is concerned. ${ }^{114}$ Both scholars nonetheless insist upon its existence. In this respect, Arajärvi and Payandeh mirror Marmor's claim that "controversy over the content of a rule of recognition does not prove that there is no such rule"115 because, allegedly, the mere fact that we disagree shows that there must be a rule with relatively free-standing content for us to disagree about.

Whilst Marmor's claim may capture the nature of our disagreements about how to interpret things like novels or paintings, it is difficult to see how it can apply to social conventions like rules of recognition. It is not unreasonable to suppose that poems, paintings, and other forms of art have at least some meaning that is independent of our beliefs about them. A poem is either a sonnet or it is not, regardless of what any particular person believes about it, and a painting is at least physically the way it is, regardless of our beliefs about it. But how can social conventions, which are entirely constituted by convergent behaviors and attitudes, have sufficiently mind-

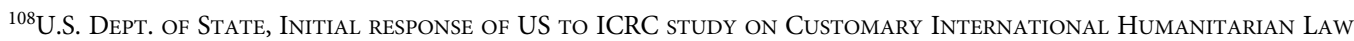
With Illustrative Comments (Nov. 3 2006).

${ }^{109} I d$.

${ }^{110}$ C.f. Military and Paramilitary Activities in and against Nicaragua (Nicar. v. U.S.), Judgment, 1986 I.C.J. 14, para. 188; with North Sea Continental Shelf (Ger./Den.; Ger./Neth.), Judgment, 1969 I.C.J. 3, para. 42.

${ }^{111}$ Compare Austl. v. France, 1974 I.C.J. at para. 43; with Nicar. v. U.S., 1986 I.C.J. at para. 40.

${ }^{112}$ Compare Aegean Sea Continental Shelf (Greece v. Turk.), Judgment, 1978 I.C.J. 3, paras. 95-107; with Pulp Mills on the River Uruguay (Arg. v. Uru.), Judgement, 2010 I.C.J. 14, paras. 138-39; and Land and Maritime Boundary between Cameroon and Nigeria (Cameroon v. Nigeria; Eq. Guinea intervening), Judgement, 2002 I.C.J. 303, paras. 262-64.

${ }^{113}$ See Jean d'Aspremont, An Autonomous Regime of Identification of Customary International Humanitarian Law: Do Not Say What You Do or Do Not Do What You Say?, in Droit InTERnATIONAL HUMANITAIRe: Un RÉGIME SPÉCIAL DE DROIT INTERnAtional? (R. van Steenberghe ed., 2013); Jean d'Aspremont, Customary International Law as a Dance Floor: Part II, EJIL:TALK! (Apr. 15, 2014), http://www.ejiltalk.org/customary-international-law-as-a-dance-floor-part-ii/; d'Aspremont, supra note 6, at 213.

${ }^{114}$ Arajärvi, supra note 32, at 373; Payandeh, supra note 5, at 991.

${ }^{115}$ ANdrei Marmor, Positive Law and Objective Values 6 (2001)
} 
independent content to enable extensive disagreement about what they entail? Try to imagine a traditional game existing even though everyone is in constant disagreement about how to understand and apply its constitutive rules, or a customary practice of queuing under which people routinely disagreed about whether it is permissible to barge past anyone standing in front of you. Imagining such things is difficult because we cannot have social conventions without significant agreement over how to apply them as rules of conduct. In the absence of extensive coincidence of belief about their content, no social conventions, including rules of recognition, can exist.

Admittedly, no one contemplating a rule thereby contemplates every instance of its application. That is not at issue here. My point is that unless we can agree about how to apply a rule in the vast majority of cases, we cannot speak of its prescriptive criteria as existing as a convention in the way that rules of recognition are supposed to exist. ${ }^{116}$ Coleman seems to disagree-at least sometimes - arguing that we may share criteria even if we markedly disagree about how to apply them. ${ }^{117}$ To use the example he gives, we may have a convention of doing things fairly but disagree about what fairness requires, so that even though we are following the same convention we disagree about how to follow it. However, as Dworkin notes, this suggestion is suspect insofar as it obliterates any distinction between convention following and other normative behavior:

[W] can easily regard any community's moral practices as resting on convention in the same way. Though Americans disagree about a great range of moral issues, they almost all agree that people should behave in the 'right' or 'proper' or 'just' way, so their less abstract disagreements are all disagreements about the correct application of their more abstract shared convention. ${ }^{118}$

If Coleman were correct, then flouting convention for moral reasons would be conceptually impossible in any society that generally believed acting morally to be important: By definition, such societies would act in accordance with convention whenever they acted for moral reasons. But if all normative behavior can be described in terms of conventions, then convention is no longer an analytically useful category.

The same holds within the international legal system. Learning that the content of international law is fixed by convergent attitudes and behavior is only worthwhile, doctrinally speaking, if this helps to identify valid law in some suitably concrete manner. Imagine a class of law students hoping to learn about the law of treaties. "States," says their professor, "are bound by the terms of relevant and valid treaties." She then turns around and leaves. Her students would be justifiably outraged. Neither "relevance" nor "validity" were sufficiently explained to them, not to mention "states" or "treaties." Even if the professor were to do a lot more fleshing out, it would be almost impossible for her students to grasp her meaning without illustrations of how this rule applies in practice. The reason that social conventions can play some part in determining the validity and relevance of treaties is because the criteria for those conventions are widely shared. ${ }^{119}$ However, at the level of abstraction at which an international rule of recognition would have to operate, there is too much disagreement for a social convention to be established. The minimal consensus view must fail.

\section{More of a 'Feeling'?}

What of d'Aspremont's suggestion that a feeling of using the same criteria is sufficient? Perhaps this is just a reiteration of the minimal consensus view, given his claim that "such a feeling will

\footnotetext{
${ }^{116}$ This is an active problem, for example, in international investment law. See Campbell McLachlan, Investment Treaties and General International Law, 57 INT'L \& COMPAR. L.Q. 361, 365-67 (2008).

${ }^{117}$ Coleman, supra note 93 , at $116,126$.

${ }^{118}$ DWORKIN, supra note 50, at 193.

${ }^{119}$ Take, for example, the linguistic conventions that determine the "ordinary meaning" of words, which aid the standard approach to treaty interpretation under Article 31(1) of the Vienna Convention.
} 
necessarily hinge on their respective understandings of formal lawascertainment criteria dovetailing to a reasonable extent." 120 In that case, it is problematic for the same reasons. However, let us assume that this is not so. What else could we be dealing with? The first possibility is that feeling means belief. But beliefs can be false. Officials who believe that they are applying the same criteria may in fact be engaged in an entirely incoherent practice. It is hard to see how a rule of recognition could exist under such conditions.

Another possibility might lie in d'Aspremont's analogy with ordinary language. He tells us that " $\mathrm{t}$ ]wo persons may well be using the same words and believe that they attribute to them the same meaning, but in actual fact are talking past each other. That, however, does not preclude that they are speaking the same language." 121 This is true. You and I may well be talking past each other if, when disagreeing about whether the United States of America is a democracy, you were using that word in its ordinary institutional sense, and I was talking about whether the US properly instantiated democratic values. To say that either of us had stopped speaking English would be absurd. However, this cannot establish the possibility of international rules of recognition. Two people applying different criteria for identifying international law are clearly both engaged in its identification. They are not speaking a different language to that extent. But this cannot establish that their criteria are non-contradictory or even similar. I suspect that d'Aspremont realizes this, which is what leads him to concede: "[T]he existence of such a feeling presupposes the ability for each law-applying authority to check whether other law-applying authorities use the law-ascertainment criterion at stake according to a similar perception."122

On the one hand, if the relevant feeling can only be present where legal officials actually check that they are applying similar criteria, then this smuggles in the extensive consensus view by the back door. On the other hand, if d'Aspremont means just that such confirmation must be available-even if it is never pursued - then we are back to equating feeling with belief. It would be naive to suppose that just because legal officials can ensure that their behavior is consistent that they do.

As the forgoing arguments show, there can only be an international rule of recognition if there are significant levels of consensus about the criteria of validity for international law. However, international practice exhibits deep and pervasive disagreement about these criteria. This casts serious doubt upon the rationality of relying upon convergent attitudes and patterns of behavior when attempting to identify international law: Building legal argument upon non-existent consensus amounts to reliance upon a false premise or fiction. Try as some might, this problem cannot be sidestepped by showing that similar difficulties plague domestic legal systems. ${ }^{123}$ Unless we are to beg the question by assuming that all legal systems must have a rule of recognition, such simple comparisons do more to evidence some general difficulties faced by Hart's positivism than to illustrate the existence of sufficient consensus within the international community.

\section{E. Conclusion}

This Article began by showing how a rule of recognition might be thought to explain international law's doctrine of sources. On this account, particular social facts are picked out as formal sources - and therefore have direct bearing upon the content of binding norms - when they are accepted as such by international legal officials. Whilst this element of Hart's philosophy enables a prima facie coherent picture of how the content and validity of international law might be fixed, I argued that it suffers from two significant difficulties.

\footnotetext{
${ }^{120}$ D'ASPREMONT, supra note 6, at 201.

${ }^{121}$ D'Aspremont, supra note 6, at 201.

${ }^{122} \mathrm{Id}$. at 202.

${ }^{123}$ See Payandeh, supra note 5, at 989-93; see also KeITH Culver \& MichaEl GIUdiCE, Legality's Borders: AN EsSAY IN GENERAL JURISPRUDENCE 29 (2010).
} 
First, although Hart was correct to suppose that we need some standard to determine which social facts fix the content of international law, no rule of recognition could fulfil this role because all such rules amount to little more than additional collections of social facts. Second, the only philosophically sustainable view of rules of recognition requires there to be such a high level of consensus regarding: (i) Which social facts count as formal sources; and (ii) what implications these sources have for the prescriptive content of particular legal norms, that it is highly doubtful whether the international legal system possesses a rule of this kind. Taken together, these two problems demonstrate serious flaws in the notion that international law ultimately rests upon a convergence of attitude and behavior amongst international legal officials, however the latter might be understood.

It pays once more to emphasize why all of this matters. It has been suggested by some scholars that international law is little more than a label given to patterns of behavior that coincide with governmental self-interest. ${ }^{124}$ This charge cannot be resisted unless it can be shown that, as an absolute minimum, international legal argument is rationally intelligible. But the immanent rationality of international law would be fundamentally undermined if it genuinely rested upon what are, in philosophical terms, foundations of sand. As this Article has demonstrated, that is precisely the result one tempts-and indeed, what some contemporary scholars actively encourage-by trying to anchor the validity and content of international legal norms in the convergent attitudes and behaviors. An international rule of recognition is either metaphysically impotent to render international law-determination rationally intelligible, or so demanding in terms of global consensus that it can play no practical role in contemporary international law. All of this is grist to the mill of those who claim that international law is nothing more than poorly disguised realpolitik. ${ }^{125}$ In my view, contemporary international law needs a normative theory of legal validity more along the lines of that advanced by Lassa Oppenheim. The challenge that lies aheadand to which this Article provides merely a deconstructive precursor-is in how to formulate such a theory in light of the international law's increasing complexity.

\footnotetext{
${ }^{124}$ See generally Goldsmith \& Posner, supra note 49.

${ }^{125}$ Martti Koskenniemi, From Apology to Utopia: The Structure of International Legal Argument 58-67 (2005).
}

Cite this article: Green A (2021). The Precarious Rationality of International Law: Critiquing the International Rule of Recognition. German Law Journal 22, 1613-1634. https://doi.org/10.1017/glj.2021.80 